\title{
Correction to: Rudolf Hilferding on the Economic Categories of 'Joint-Stock Company/Share Capital': A Refinement of the Critique of Political Economy?
}

\author{
Judith Dellheim
}

\section{Correction to:}

Chapter 13 in: J. Dellheim, F. O. Wolf (eds.), Rudolf Hilferding, Luxemburg International Studies in Political Economy, https://doi.org/10.1007/978-3-030-47344-0_13

The book was inadvertently published with an error to the equation in Chapter 13 (page 315 of the PDF). The equation has been updated.

The updated version of the chapter can be found at https://doi.org/10.1007/978-3-030-47344-0_13

(C) The Author(s) 2021

J. Dellheim, F. O. Wolf (eds.), Rudolf Hilferding, Luxemburg International Studies in Political Economy, https://doi.org/10.1007/978-3-030-47344-0_15 